\title{
A LEARNING CURVE THEORY PERSPECTIVE ON PROJECTS. RANKING THE KEY DETERMINANTS TO IMPROVE PROJECT EFFICIENCY
}

\author{
E. Hattingh ${ }^{1 \#}$, C.C. van Waveren ${ }^{1} \&$ K.-Y. Chan ${ }^{1 *}$
}

\section{ARTICLE INFO}

\section{Article details}

Submitted by authors 7 Dec 2017

Accepted for publication 28 Jan 2019

Available online 29 May 2019

\section{Contact details}

* Corresponding author alice.chan@up.ac.za

Author affiliations

1 Department of Engineering and Technology Management, University of Pretoria, South Africa

\# The author was enrolled for an MEng (Project Management) degree in the Department of Engineering and Technology Management, Graduate School of Technology Management, University of Pretoria.

\section{ABSTRACT}

The desire to gain knowledge about the quality and timing of construction projects delivered to clients has become an increased focus point in the field of construction management. Clients have expectations that are often based on their assumptions about the validity of making the learning curve theory applicable to construction projects. This research aims to determine what criteria need to be met for the learning curve theory to have some validity for construction projects. The results from the questionnaire survey, completed by professionals from the construction industry, show that several concepts were found to be of importance: project specifications, design, scope, budget, site management, planning, monitoring and controlling, and quality. If these concepts correspond between two projects, the chance of successfully applying the learning curve theory increases. Practical recommendations are made that highlight the concepts identified as critical for the successful application of the learning curve theory to construction projects, and that can be used by clients and contractors as a basis for negotiating project schedules.

\section{OPSOMMING}

As deel van die evolusie in konstruksiebestuur het kennis van projekkwaliteit asook die tydsduur van konstruksieprojekte ' $n$ groter noodsaaklikheid geword. Kliënte het verwagtinge wat dikwels gebaseer word op persoonlike aannames rondom die geldigheid van die leerkurweteorie en die toepaslikheid daarvan op konstruksieprojekte. Die doel van hierdie navorsing is om die projekkriteria te bepaal wat in plek moet wees om die geldigheid van die leerkurweteorie op konstruksieprojekte te bevorder. Die uitslag van die opnamevraelys, wat deur professionele persone in die konstruksiebedryf voltooi is, het getoon dat daar verskeie kriteria van belang is, naamlik: die projekspesifikasie, die ontwerp en omvang van die projek, die begroting, die bestuur van die konstruksiewerf, die beplanning, monitering en kontrole, asook die kwaliteitverwagtinge van die projek. Indien meerdere van hierdie kriteria tussen twee projekte ooreenstem, verhoog dit die kans dat die leerkurweteorie suksesvol van een projek na 'n ander toegepas kan word. Ter afsluiting word praktiese aanbevelings gemaak wat die belangrike kriteria uitlig wat nodig is vir die suksesvolle toepassing van die leerkurweteorie op konstruksieprojekte. Hierdie aanbevelings kan deur kliente en kontrakteurs gebruik word as ' $\mathrm{n}$ basis tydens die onderhandeling van projekskedules vir opkomende en soortgelyke projekte.

\section{INTRODUCTION}

In the construction industry, each construction project is unique. However, there is still a large amount of repetitive work, and there are many similarities among the projects that a company 
handles simultaneously, or between a current and a past project. It is safe to say that construction projects can, to a large degree, be described as repetitive work. Too often a project manager is forced to manage a project that has a reduced schedule and a limited budget - reductions that are enforced by management and clients, based on their preconceived idea that the project must automatically finish earlier (or more cheaply), because a similar project was successfully completed with the same constraints by the same company in the past. Many are blinded by the fact that the learning curve exists, and therefore they assume that a project that is in some way similar to a past project will positively gain from the learning acquired in the past. This assumption can have devastating effects on the successful completion and outcome of the project. The aim of this study is to determine to what degree the learning curve theory can be applied to construction projects, even when these projects are not exactly the same. It must be noted that, although projects might be similar to some degree, the ultimate deliverable of each project will differ in some way.

Should it be possible to prove that learning can be transferred from one project to another that is similar, but that the criteria applicable to these projects (as indicated in this research) do not match sufficiently to allow for a reduction in schedule or budget, companies will be in a better position to negotiate with clients during the tendering process. Clients usually choose companies with previous experience in a relevant field to tender on their projects. For example, companies with a successful history in the construction of electrowinning plants for copper extraction are usually approached to tender for new projects that involve electrowinning plants. The problem is that the client then negotiates a reduced schedule, based on the company's last successful construction of a similar plant. If it took the company 16 months to build a similarly sized plant in the past, the client will argue that, due to the learning the company has gained during that project (in accordance with the learning curve theory), the current project schedule should be reduced to less than 16 months. Such an assumption is not entirely correct, as the schedule can also be affected by non-technical related aspects, such as stakeholder engagement requirements and communication protocols set by the client. To investigate the possible validity of the learning curve theory and the assumption that prior learning should always reduce cost and time, this study determines which concepts related to a project can be directly linked to the learning curve theory. Answers to the following questions will thus be sought: What similarities are needed in order for learning to be passed on from one project to the next? Can the learning curve theory be used as motivation for reduced schedules, and possibly budgets, on such projects?

The authors' preliminary investigation of the research topic revealed that various construction projects involve some degree of repetitive work. Proponents of the learning curve theory posit that proficiency increases with experience; yet an increasing number of projects are over budget, over schedule, or both. It is not clear to what extent the learning curve theory holds true for construction projects, and in particular for the construction of a building, plant, or structure where some repetition, previous learning, and knowledge transfer play a role. It needs to be explored whether the learning curve theory can be applied to construction projects that are generally not repetitive in all respects, but that do contain elements of repetition if previous projects are taken into account.

Until now, the exact criteria for the application of the learning curve theory to construction projects were not known. The current body of knowledge does not deal with the application of the learning curve theory to construction projects. Projects are, in essence, a unique set of operations, whereas the learning curve theory was developed in an industry where exact repetitions are the order of the day.

The objective of this research is to determine whether the learning curve theory can be applied directly to construction projects. In investigating the application of the learning curve theory to construction projects, the focus will be on compiling a specific set of criteria that can be used to determine whether a past and a new project match, in order for a contractor to accept that the learning gained from a past project can be applied successfully to a new project. The main research question is: On construction projects, which criteria applicable to past and current projects within the same company need to correlate in order for the learning curve theory to hold true? To answer this question, it would need to be determined what items must be identical between two similar construction projects to ensure that the 'learning' gained on one project can be transferred to the next project. 
The learning curve theory was first described in 1885 by Hermann Ebbinghaus, primarily in the field of psychology. It was not until World War II that T.P. Wright described the effect of the learning curve in the aircraft manufacturing industry [1]. At that time it was noted that the labour units required to manufacture fighter aircraft decreased as the number of planes built increased. This led to the realisation that a certain amount of learning took place with the manufacture of each aircraft. The people assembling the aircraft learned how to do their work in a quicker and more efficient manner. Until now, the learning curve theory has been applied mostly to work that is repetitive in all respects, such as work on production lines and assembly lines in factories. The learning curve theory can be described in terms of the relationship between experience and productivity.

Construction projects have the benefit that the work involves a certain degree of repetitiveness. In the mining and minerals processing industry, areas within a plant are largely copies of plants built previously. Depending on the number of ore deposits involved and the rates of production, electrowinning plants used in copper extraction are identical. The same is true for housing developments: even though house plans and layouts might differ, the foundation design for, and the construction of, single-storey houses is largely the same. Building single-storey houses is fairly standard, and many of the elementary tasks involved, such as fitting a bathtub, are repetitive. On each construction project, a certain amount of learning takes place, even though the details are not exactly identical (as is the case with work in assembly or manufacturing plants).

\subsection{General learning curve theory}

The view of Stump [2] is that the learning curve theory can be applied to determine costs on construction projects when structures are repeated. As the meaning of the word 'repeated' is not specified, it is unclear what degree of duplication is needed to make the statement true. Henderson [3] believes that the use of a learning curve carries a significant risk of error, unless the true limitations and characteristics of the learning curve are understood. He adds that, even though the learning curve holds immense value, it has been misapplied in the past. However, he does not explain how the learning curve should be applied to ensure a relatively low risk of error. The misapplication and misconception of the learning curve has caused a loss of confidence in the whole concept, and has created doubt about its usefulness. Nevertheless, Henderson's statement is valuable enough to provide a reason for determining whether it is true for construction projects. In the current research, the focus is on exploring the misapplication of the learning curve theory, and in particular the ways in which management misapplies this theory to lower project costs.

According to Hodder and Ilan [4], production costs decline as experience increases. This statement is very broad, and it does not take the details of each project into account. Nevertheless, clients who negotiate lower prices for so-called repetitive construction projects use the reasoning put forward by these authors. Apart from a reduction in cost, another important factor is a reduction in the time required to complete a specific task, action, or project [2]. The reason for this could be that cost is directly related to the time it takes to complete an activity.

\subsection{Factors influencing the learning curve}

Over the past 70 years, the learning curve theory has successfully been applied to various industries, including the aeronautic, automobile, electronic, shipbuilding, petroleum, power generation, and steel industries [5]. Only over the last 40 years has the learning curve gradually been introduced into the construction industry; and until now, the learning curve has largely been implemented to determine the contract pricing of a construction project. The learning curve theory has also been applied in situations where the work performed is repetitive in all respects.

Thomas, Mathews and Ward [6] made one of the most important findings about the learning curve theory - that the learning curve can only be applied to identical, repetitive, and continuous work. Considering this statement in isolation, therefore, it can be argued that the learning curve cannot be applied to most construction projects as they are, to a large extent, not 100 per cent identical or repetitive. Most projects are also not continuous: there is usually a time interval between the end of one project and the start of the next one; and for that reason, at least some learning will be lost. Projects are unique ventures that make use of standard repetitive processes. The more these processes are repeated, the more experience is gained, and the more the cost and required resources are expected to decrease [7]. 
Contractors in the construction industry do consider the learning curve theory when they prepare an estimate or tender for a new project. The contractor usually draws up a baseline project rate at the end of a project, looks at the actual number of hours spent to complete the work, and then files this information together with other notes about the project to use when preparing a bid for a future new project [8]. These notes will include items such as site conditions, names of team members who worked on the project, and records of work. When a new project comes up, these notes are retrieved and used to adjust the budget and schedule, based on the number of similarities between the past and the future project. If a task is repetitive in all respects, the contractor will know that a noticeable improvement in efficiency can be expected. How to quantify this improvement is still a big challenge to any contractor, as it depends on the type of construction activity [8]. Some of the first studies on the use of the learning curve in construction projects were conducted by Parker and Oglesby [9], who noted that an improvement in productivity (from 10 to 30 per cent, depending on the complexity of the tasks) could be expected when repetitive construction tasks were performed. Further studies have revealed that there is a significant positive effect on the efficiency of any construction activity if that activity is repetitive in nature and is carried out by exactly the same crew [8].

The research of Pellegrino et al. [8] ties in with the findings of Thomas et al. [6], where the learning curve is only applicable to identical, repetitive, and continuous work. However, no research has answered the question about the criteria that are needed for the contractor to assume that a certain amount of learning from a previous project can be applied to a current project, even though the projects are not identical and the line of continuity between them has been broken. The effect that repetition has on a construction project is undeniable, and is not merely a theoretical concept; yet the exact effect it has is apparently unquantifiable [10]. Independent concepts that improve the efficiency with which a project can be delivered need to be investigated; and it also needs to be determined whether these concepts are repetitive, continuous, or identical factors, as Thomas et al. [6] describe.

\subsection{Independent concepts that improve construction project efficiency}

The current theory available on the learning curve deals with the mathematical or quantitative approach to the learning curve, but not with the qualitative approach. This is what the current research study sets out to do. In an effort to expand on existing theory, the current study will also break down the three important factors (the need for tasks to be identical, repetitive, and continuous) that have been identified for the learning curve to succeed and, from a qualitative perspective, identify what the important concepts are for a task to be deemed repetitive, identical, and continuous. A proposed example of the breaking down of these three factors can be seen in Table 1.

Table 1: Proposed qualitative criteria describing the three learning curve factors

\begin{tabular}{|l|l|}
\hline \multirow{2}{*}{ Identical: } & Identical project manager \\
\cline { 2 - 2 } & Identical geographical location \\
\hline \multirow{2}{*}{ Repetitive: } & Same team constructing foundations of same dimensions \\
\cline { 2 - 2 } & Same team constructing the structure of the same size \\
\hline \multirow{2}{*}{ Continuous: } & Time lapse of approximately a week between projects \\
\cline { 2 - 2 } & Time lapse of approximately a month between projects \\
\hline
\end{tabular}

Because the construction industry comprises such a large field, the theory dealt with in this study will be narrowed down to relate only to the construction of mineral processing plants. In order to identify which concepts form part of the identified repetitive, identical, and continuous factors, the research looked at general project management and real-world input from the industry. As this research is directly linked to project management and the possible influences on project outcomes, certain key issues dealt with in the project management body of knowledge (PMBoK) [11] were taken into account as factors that could affect the successful application of the learning curve theory to construction projects. The author of the current study identified 17 concepts in the above publication that could have a direct impact if the factors relating to a previous project were used to plan or manage a current project. These concepts are: schedule, scope, quality, risks, project specifications, location, communication protocol, stakeholders, project team, project manager, 
client, project sponsor, deliverables, availability of suitable resources, contract methodology, reporting and feedback, and organisational structures.

In an earlier edition of the above publication [12], several of the above concepts were mentioned; seven additional concepts were also mentioned that could have a direct impact when factors related to a previous project were applied to the next project. These additional concepts are time management, budget, procurement methodology, human resource management, claim management, financial management, and safety standards and management.

Schwartzkopf [13] also comments on concepts that increase the productivity and efficiency of projects. Although not all of the concepts he mentions will have a direct impact from one project to the next, the ones that, in the opinion of the author, are most likely to have an impact, are: coordination of crew, engineering liaison, day-to-day management, efficiency of material usage, efficiency of material delivery, construction methods, space for crews to work in, job familiarisation, and design. Similarly, Pellegrino et al. [8], who have studied project efficiency, identify the following concepts as the ones that are most likely to have a direct impact from one project to the next: size of construction crew, site management, storage area setup, and weather.

In the opinion of the author of the current study, changes in certain concepts are also very important to consider from one project to the next, as they could have an impact on the outcome of the project. These concepts were identified after discussion with various members of staff who work in the construction environment. These concepts are: construction materials, sequence of construction, construction tools available, repetition of work, and experience of construction crew. All 42 concepts are listed, in no specific order, in Table 2.

Table 2: Identified qualitative concepts that could have a direct impact on project learning curve outcome

\begin{tabular}{|l|l|}
\hline Schedule & Human resource management \\
\hline Scope & Claim management \\
\hline Quality & Financial management \\
\hline Risks & Safety standards and management \\
\hline Location & Coordination of crew \\
\hline Communication protocol & Engineering liaison \\
\hline Stakeholders & Day-to-day management \\
\hline Project team & Material usage efficiency \\
\hline Project manager & Material delivery efficiency \\
\hline Client & Construction methods \\
\hline Project sponsor & Space for crews to work in \\
\hline Deliverables & Job familiarisation \\
\hline Availability of suitable resources & Design \\
\hline Contract methodology & Size of construction crew \\
\hline Reporting and feedback & Site management \\
\hline Organisational structures & Storage area setup \\
\hline Time management & Weather \\
\hline Budget & Construction materials \\
\hline Procurement methodology & Construction sequence \\
\hline Repetition of work & Construction crew experience \\
\hline & Construction tools available \\
\hline
\end{tabular}

Although 42 concepts were identified that could have a definite impact on the possible successful application of the learning curve theory to construction projects, the possibility exists that there 
could be more concepts; therefore, the group of experts taking part in this research were given the opportunity to add any concepts they feel are important. An unexplored aspect to which the current research will also attend is the categorisation of each of these concepts under the factors of repetitive, identical, or continuous tasks, and ranking these concepts in their order of greatest importance for the successful application of the learning curve theory to construction projects.

\section{CONCEPTUAL FRAMEWORK}

As seen in the literature review, there is a large gap in the theory about a qualitative approach to the identical, repetitive, and continuous factors that are critical for the learning curve to be applied to the construction industry. To address this gap, this study will focus on theory building and, using the existing theory to gather data, introduce an updated or improved theory, method, or model based on the results. No hypotheses are generated for this study, with the new theory or model being the primary outcome of the research.

The independent variables, as indicated in Figure 1, are the identical, repetitive, and continuous factors that have an impact on the application of the learning curve theory [6]. In the current study, these factors will be manipulated by breaking them down into concepts to determine their effect on the problem being investigated. In essence, these concepts are the practical, qualitative criteria describing each factor and forming the basis of the successful application of the learning curve theory to construction projects. The research will focus on how these three factors and their associated concepts typically apply to construction projects in general. By changing or manipulating the independent variables, their impact on the successful application of the learning curve theory to construction projects can be explored. The three independent variables, with typical examples of each, are depicted in Figure 1.

Independent variables

Repetitive Factors
- Possible concepts
Day-to-day management
Construction methods
Schedule
etc.

Dependent variable

Figure 1: Conceptualised relationship between variables

The conceptual model followed in this research consists of the three independent variables (or factors) and their concepts. The model focuses on an exploration of the impact of these factors and concepts on construction projects within the realm of the identified problem statement - the successful application of the learning curve theory to construction projects. The approach to determining which concepts form an important part of each individual factor was based on the opinion of the experts in the field (to avoid the subjective opinion of the researchers). Details of this approach are described in the 'method' section of this paper. Once the important concepts had been determined, they were discussed, evaluated, and categorised per factor. A Delphi study was used and a questionnaire administered to the participants (who are experts), in which they were asked to rank the concepts in order of importance. The purpose of using this method is to determine which of the concepts, classified under each of the independent variables or factors, are nonnegotiable for the successful application of the learning curve, leading to possible project success 
and, in the end, to achieve the objective of addressing the research problem related to the successful application of the learning curve theory to construction projects.

The three independent variables and their associated concepts were analysed and discussed from a qualitative point of view. In the investigation into the possibility of applying the learning curve theory to construction projects, the independent variables and their associated concepts were expected to reveal the possibility of either verifying or disqualifying the application of this theory to construction projects. Figure 2 depicts a conceptual method for the successful application of the learning curve theory to construction projects, and a resultant increase in the possibility of overall project success. The exact effect on project success will not be explored in this research, but the suggested method serves as a good basis for future research. However, it is important to realise that the process does not stop until knowledge transfer has taken place, and that the process links back indirectly to the independent variables. Without knowledge transfer, repetitive, identical, and continuous momentum is lost, which leads to a breakdown of the theory in itself. Even though knowledge transfer is not specifically mentioned in the literature review, it is an important cornerstone of the successful application of the learning curve theory to construction projects. For the purpose of this research, it is assumed that organisational learning and knowledge transfer between project members and stakeholders, and specifically within the relevant company, are successful. The independent variables are studied to gain a better understanding of their impact on a construction project.

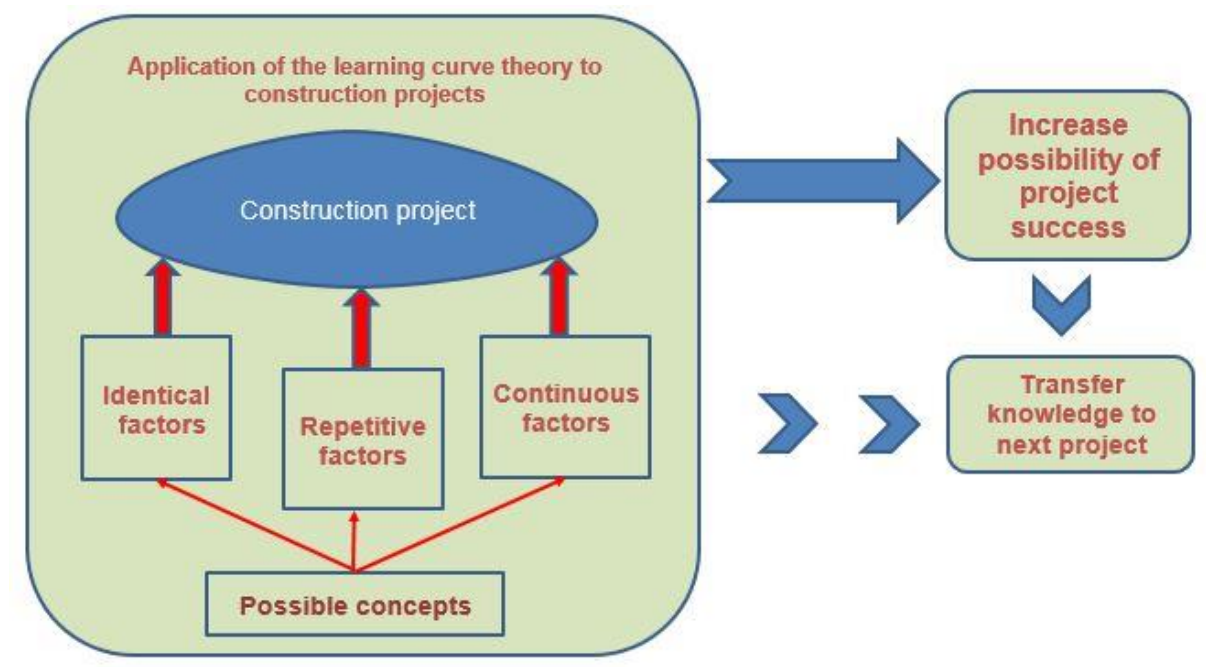

Figure 2: Conceptual method used to investigate the application of the learning curve theory to construction projects

\section{RESEARCH METHOD}

The research was broken down into two phases, with the first phase being the investigation that explored, confirmed, and categorised the concepts according to identical, receptive, and continuous factors, as noted during the literature study. These concepts were then confirmed by a group of experts using a Delphi study; this consisted of an expert group of 10 project managers, all working for construction companies and project houses specialising in Engineering, Procurement, Construction Management (EPCM) contracting methodologies. The first phase is discussed by the authors in a separate document [14]. In the second phase, the research went further and ranked the identified concepts in order of importance, using questionnaires that were administered to a larger group consisting of project managers, project engineers, and planners, all working for construction companies and project houses specialising in EPCM contracting methodologies in the construction industry. This article only highlights the results obtained during the second phase (concept ranking). The remainder of this section describes the survey method in the second phase in more detail. 


\subsection{Concept ranking using the survey questionnaire technique}

The main goal of the survey questionnaire used for the current study was to gain constructive insight into the opinions of the selected respondents, and to establish their views about the application of the learning curve theory to construction projects. The questionnaire focused on ranking the different concepts of the learning curve theory. The concepts were identified during the literature study, and further explored, confirmed, and categorised according to identical, receptive, and continuous factors during the first phase of the research. (The first phase of the research is not discussed further in this article.) In this study, the questionnaire was distributed electronically using an innovative web-based program that required the selected sample group to access the questionnaire via a web page in order for each respondent to complete the survey anonymously. The hyperlink to the web page was distributed by the researcher to each individual respondent via email. It was possible to monitor responses electronically throughout the process, and all responses were recorded in a central database. The program allowed respondents to start and complete the survey at any time. Reminders were sent to the respondents via e-mail two weeks after the initial distribution of the questionnaire, and this was followed up with weekly reminders. An overview of the study objectives was provided to the respondents at the start of the questionnaire, and great emphasis was placed on the confidentiality of the information provided. All respondents were requested to answer an informed consent question at the start of the questionnaire to ensure that they understood that their participation was voluntary. Great care was taken to ensure that the questionnaire questions conformed to internationally accepted standards.

\subsection{Sampling method}

A purposive sample was required for the questionnaire. The participants were selected on the basis of their knowledge and expertise to understand and answer the research questions. In other words, the sample was not chosen to be representative of the general population, but rather of a specific expert group. The purposive sample selected for the survey questionnaire research study consisted of respondents who were perfect fits according to the qualifying criteria of Hsu and Sanford [15]. The participants were project managers, project engineers, and project planners employed by active construction companies and project houses specialising in EPCM contracting methodologies in the construction industry. The respondents in the sample all had tertiary qualifications, were actively involved in the day-to-day project management of construction processes, and had more than five years' experience in the construction industry. All the respondents were willing to participate. Neither gender nor race formed part of the selection criteria, and all the respondents were proficient in English. Although the participants were working in South Africa at the time that the data for this research was collected, they had international experience in construction projects; therefore, their responses to the questionnaire were not based on the South African context, but on their accumulated experience in construction projects around the world.

\subsection{Data collection instrument and procedure}

Questions in the form of a questionnaire were chosen as the primary data collection instrument for the survey study. Watkins [16] explains that questionnaires fall under the broader definition of survey research methods. The aim of the questionnaire used in this survey was to establish the opinions and thoughts of the respondent group about the specified problem. Survey questionnaires are well-suited to obtain the opinions, convictions, or beliefs of respondents about a certain topic or issue.

The survey questionnaire used in the research comprised closed-ended questions, and the focus was on rated response methods using the Likert scale. The Likert scale [17] is a response scale primarily used in questionnaires to obtain participants' opinions, preferences, or level of agreement about a statement made in the questionnaire.

\subsection{Reliability and validity}

Watkins [16] explains that 'reliability' refers to the degree to which the same results would have been obtained if another researcher had conducted the research in the same way. The reliability of the current research was maximised by eliminating data collector bias. As the researcher was the only administrator and collector of the data, reliability was increased. Watkins [16] further explains that the 'validity' of a research study is the degree to which the finding is a reflection of what is actually being studied, and of the reality of the situation. Internal and external validity is also largely associated with the size of the population group and the sample group. The questions in the questionnaire were based on the findings in the existing literature and on the knowledge gained 
during the literature review phase. Content validity was ensured by using clear and simple language in the questions. The questionnaires were distributed simultaneously to the respondents. Each questionnaire contained clear instructions to prevent confusion or misunderstanding. As the respondents had no knowledge of the other participants, they could not discuss the questions with each other or influence each other's opinions. All the respondents who had been approached had agreed to participate in this study. The author acknowledges that there will be some amount of error in any data collected [18]; but in the current study he strove to minimise any error in the results through the implementation of the measures mentioned in this section.

\section{RESULTS}

From the data gathered and analysed, it is clear that the learning curve theory is, first and foremost, a very familiar topic within the industry, and that many project managers, engineers, and planners have been confronted with the application of this theory on construction projects in the past.

During the first phase of the research, using a Delphi study, the expert group agreed on 50 concepts that they deemed critical to be the same, or at least to have a very high degree of similarity, between two projects. As seen in the findings of Thomas et al. [6], the expert group further categorised these concepts as identical, repetitive, or continuous factors. In the second phase, where a survey using questionnaires was conducted with the purpose of ranking the 50 concepts previously identified during the Delphi study, these concepts were ranked using a Likert scale of importance, with the aim of identifying the top ten most important concepts.

The data obtained from the survey questionnaire was analysed using the non-parametric statistical Friedman test, due to the nature of the data being ordinal (and using a five-point Likert scale of importance). This test involves ranking each row (i.e., across the 50 concepts with the highest possible rank value of 50), and then considering the values of the ranks by columns (i.e., taking the mean of these ranks, known as mean rank) as an indication of the importance of these concepts (the higher the mean rank value, the higher the importance). The top ten concepts are identified, based on the top 10 highest mean ranks.

\subsection{Concept ranking}

Herewith follows a full analysis of the results obtained during the survey questionnaire.

- 81 respondents were approached.

- 54 respondents participated.

- 11 responses were invalid.

- 43 responses were valid for all the questions.

A total of 66 per cent of the targeted sample population participated, but only 53 per cent of the responses were complete and valid. Therefore, the response rate was 53 per cent, which is higher than the response rate estimates for online surveys provided by the various authors cited by Nulty [19]. The survey questionnaire for this study was carefully designed, and participants' responses were carefully captured for analysis.

Questions 1 to 3 of the survey questionnaire covered the following aspects: the invited respondents had received permission from their companies to participate in the survey questionnaire; their participation was voluntary; and the respondents provided confirmation of their work experience. If they answered 'no' to any of the questions that required a 'yes' answer, they could not continue taking part in the study.

\section{Question 4: Are you familiar with the learning curve theory used in the manufacturing industry?}

In answer to this question, 83.7 per cent of the respondents stated that they were aware of and familiar with the learning curve theory. Of the respondents, 11.6 per cent were not familiar with the theory, and 4.7 per cent were unsure about being familiar with it.

Question 5: Has a client on a construction project ever used the learning curve theory argument to renegotiate project durations or project costs? 
In all, 62.8 per cent of the respondents indicated that a client had confronted them with the learning curve argument with a view to reducing the budget or the schedule of a project. Of the respondents, 32.6 per cent indicated that they had never been confronted by a client with the learning curve argument with a view to reducing the budget or schedule of a project, and 4.8 per cent of the respondents were unsure whether they had experienced this.

Question 6: Do you personally believe that the learning curve theory can be successfully applied to a construction project?

Of all the respondents, 69.8 per cent believed that it was possible to apply the learning curve theory to construction projects, whereas 16.3 per cent believed it was not possible, and 14 per cent were unsure whether it was possible.

Question 7: The following concepts are identified as possible critical items for the successful implementation of the learning curve theory on construction projects. Should these items change from one project to the next, the outcome of the project might be significantly influenced. How do you rate the importance of each concept?

\subsubsection{Results: All responses}

Based on the mean rank values from the Friedman test, and taking all the responses into account, the 10 most important concepts in terms of having to be the same or having a high degree of similarity were the following:

1. Project specifications

2. Design

3. Scope

4. Budget

5. Site management

6. Construction crew experience

7. Planning, monitoring, and controlling

8. Quality

9. Project manager

10. Contractor/client relationships

The above concepts are ranked in descending order of importance. Figure 3 gives a graphic depiction of the respondents' rating of the concepts according to value based on mean ranks. The ranking was determined based on all the responses provided. Those rated as having the highest values were indicated to be the most important concepts.

The research also determined the views of the respondents, based on their answers to Question 6: "Do you personally believe that the learning curve theory can be successfully applied to a construction project?" Of the respondents, 69.8 per cent believed it was possible to apply the learning curve theory to construction projects, whereas 16.3 per cent believed it was not possible, and 14 per cent were unsure whether this was possible. Furthermore, the difference between the views of the 69.8 per cent of respondents who believed it was possible to apply the learning curve theory to construction projects and the 16.3 per cent of respondents who believed it was not possible was obtained in Question 7 and analysed. The respondents' answers to this question, which required them to rate each identified concept as an identical, a repetitive, or a continuous factor, were regarded as important to understanding the overall ranking.

\subsubsection{Results: Respondents who believed it was possible to apply the learning curve theory to construction projects ( $Q 6=$ yes)}

Based on the mean rank values from the Friedman test, and according to all the 'yes' responses to Question $6(\mathrm{Q} 6=$ yes $)$, the 10 most important concepts in terms of having to be the same or having a high degree of similarity were the following:

1. Project specifications

2. Scope

3. Design and Construction crew experience

5. Planning, monitoring, and controlling 
6. Quality

7. $\quad$ Site management

8. Using the same suppliers/manufacturers

9. Contractor/client relationships

10. Budget

The above concepts are ranked in descending order of importance, with 'design' and 'construction crew experience' ranking as equally important in third position. Figure 4 is a graphic depiction of the respondents' rating of the concepts according to value, based on the mean rank values. The ranking was determined based on respondents' 'yes' answers in Question 6 (Q6 = yes). Those rated as having the highest values were indicated to be the most important concepts.

5.1.3 Results: Respondents who did not believe it was possible to apply the learning curve theory to construction projects $(Q 6=n o)$

Based on the mean rank values from the Friedman test and the respondents' 'no' responses in Question $6(\mathrm{Q} 6=\mathrm{no})$, the 10 most important concepts in terms of having to be the same or having a high degree of similarity were indicated to be the following:

1. Project specifications

1. Design

1. Deliverables

4. Scope

5. Budget

5. Planning, monitoring, and controlling

7. Client

8. Site management

9. Quality

10. Project manager

These concepts are ranked in descending order of importance, with 'project specifications', 'design', and 'deliverables' ranking as equally important in first position, and 'budget' and 'planning, monitoring, and controlling' equal in third position. Figure 5 graphically depicts the respondents' rating of the concepts according to value, based on the ranked mean method. The ranking was determined based on respondents' 'no' answers in Question $6(\mathrm{Q} 6=$ no). Those rated as having the highest values were indicated to be the most important concepts. 


\section{Mean rank values}

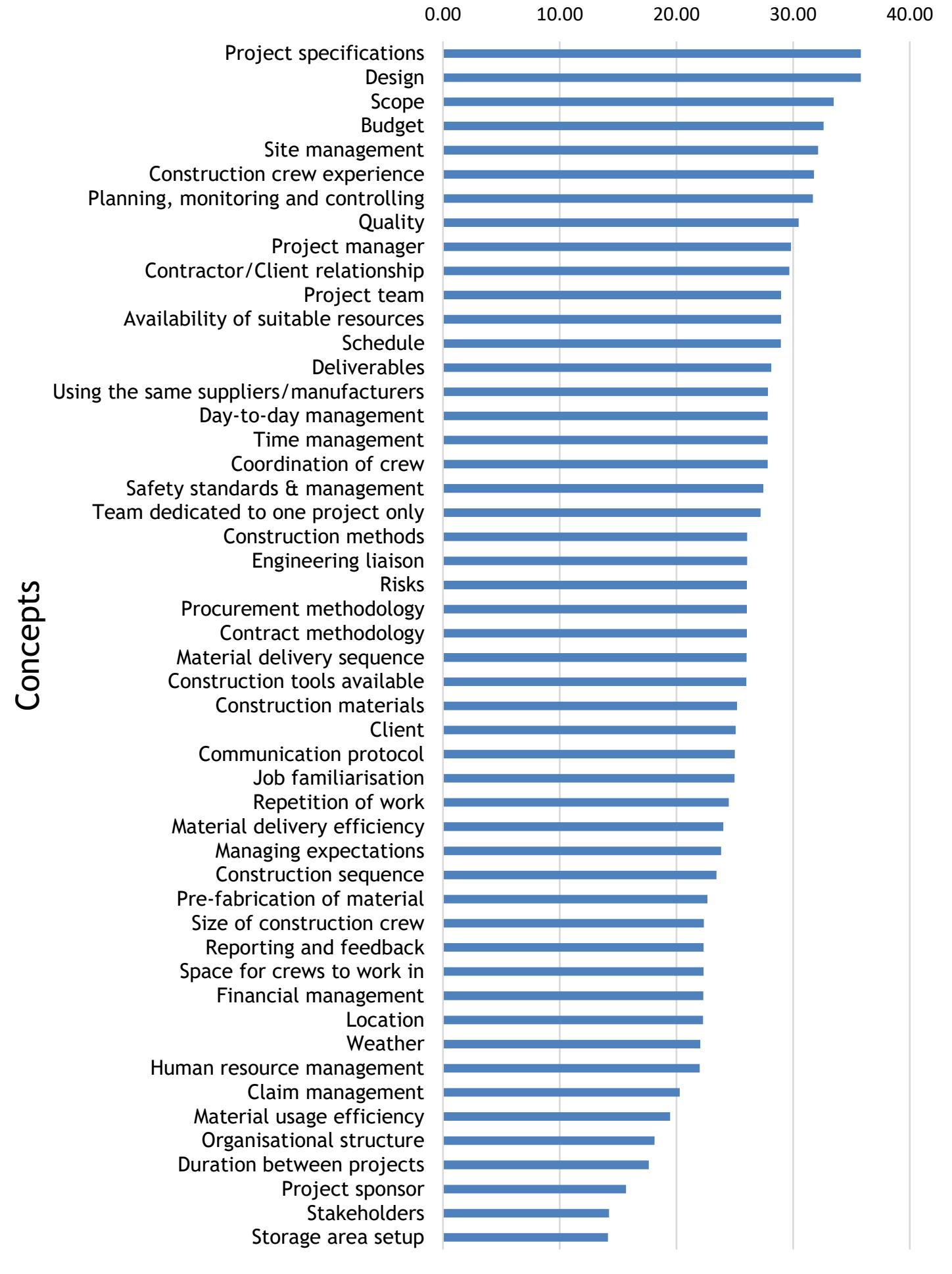

Figure 3: Critical concepts ranked according to the mean rank value (all responses) 


\section{Mean rank values}

$\begin{array}{llllll}0.00 & 10.00 & 20.00 & 30.00 & 40.00\end{array}$

Project specifications
Scope
Construction crew experience
Design

Planning, monitoring and controlling

Quality

Site management

Using the same suppliers/manufacturers

Contractor/Client relationship

Budget

Project manager

Project team

Team dedicated to one project only Schedule

Availability of suitable resources

Time management

Construction methods

Engineering liaison

Construction materials

Deliverables

Risks

Construction tools available

Day-to-day management

Repetition of work

Procurement methodology

Contract methodology

Job familiarisation

Safety standards \& management

Coordination of crew

Material delivery sequence

Pre-fabrication of material Managing expectations

Material delivery efficiency

Communication protocol

Financial management

Construction sequence

Size of construction crew

Client

Duration between projects Human resource management

Claim management Location

Reporting and feedback Material usage efficiency

Space for crews to work in Weather

Organisational structure

Stakeholders

Project sponsor

Storage area setup

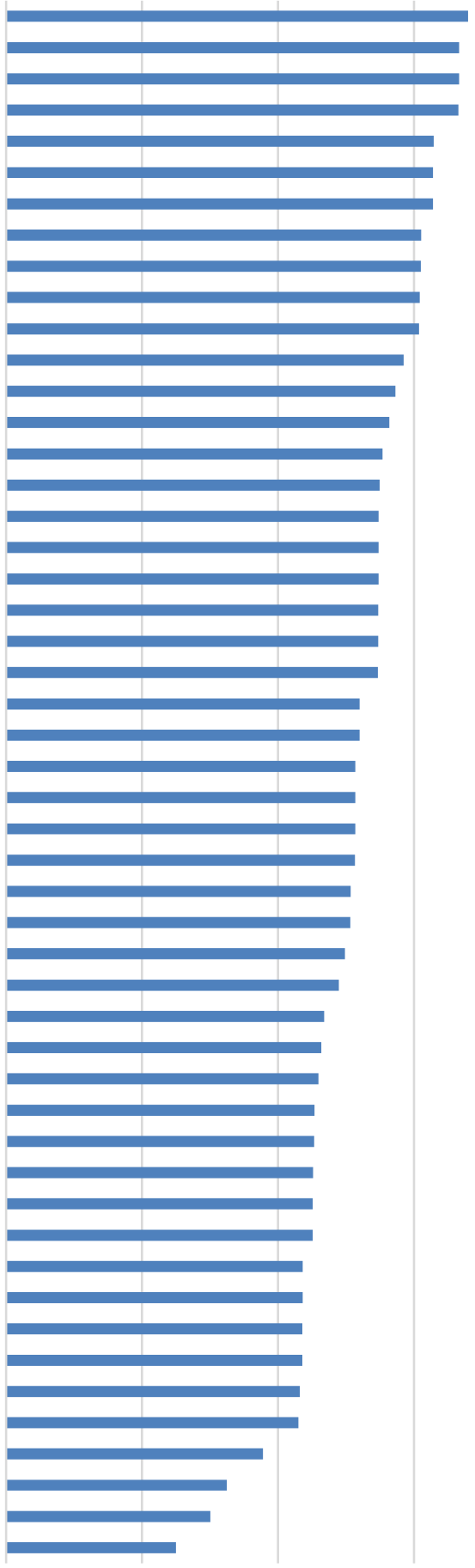

Figure 4: Critical concepts ranked according to the mean rank value (Q6 = yes) 


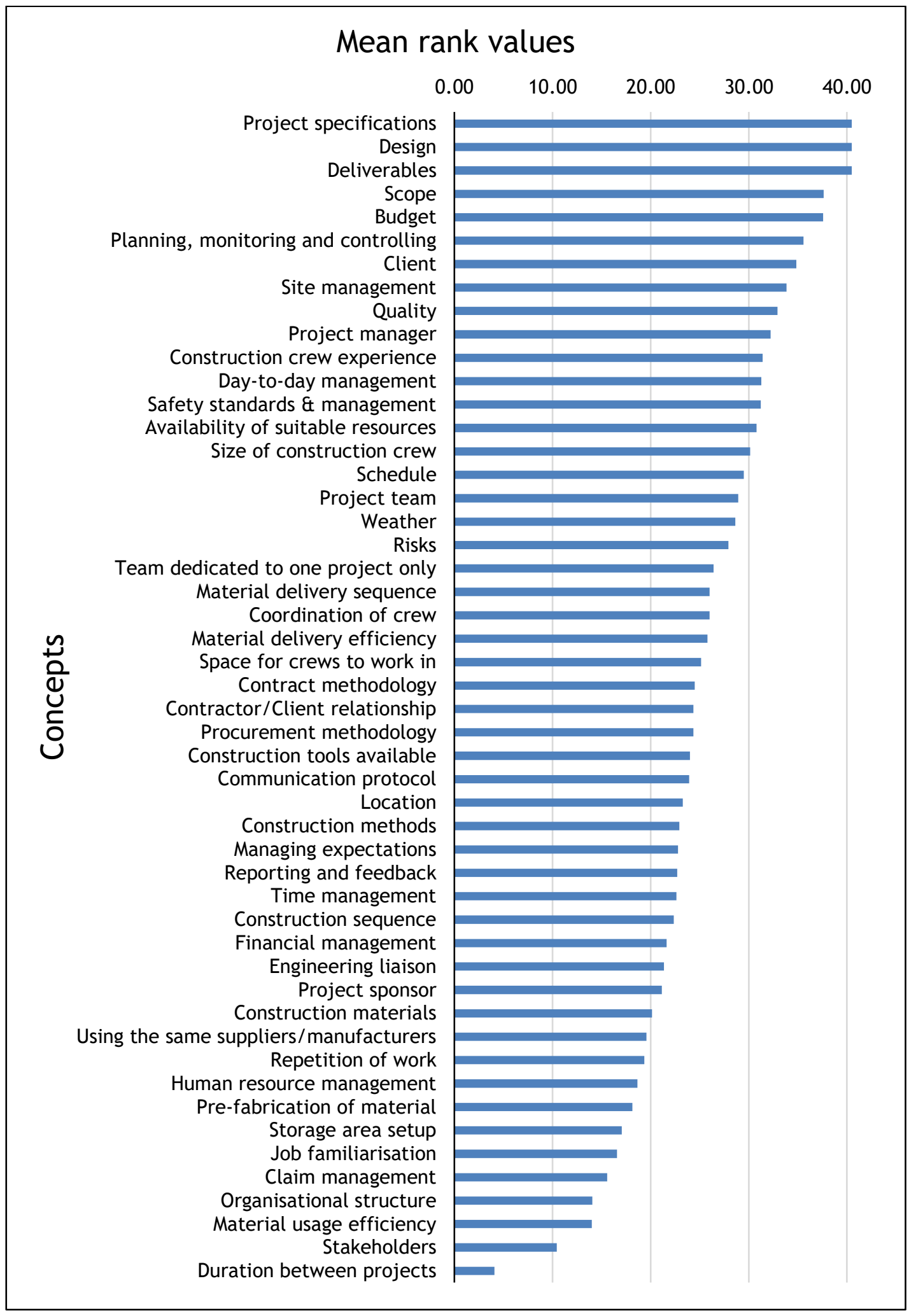

Figure 5: Critical concepts ranked according to the mean rank value $(\mathrm{Q} 6=\mathrm{no})$ 
In the survey questionnaire, the respondents ranked the concepts in order of importance, and their responses were analysed using the weighted mean and ranked mean methods. The research was expanded in that the views of the respondents, expressed in their answers to Question 6, were determined. In Question 6, the respondents were asked to respond to the following question: "Do you personally believe that the learning curve theory can be successfully applied to a construction project?" Of the respondents, 69.8 per cent believed that it was possible to apply the learning curve theory to construction projects, 16.3 per cent believed that it was not possible to apply the learning curve theory to construction projects, and 14 per cent were unsure whether it was possible. Furthermore, the difference between the views of the 69.8 per cent of respondents who believed it was possible to apply the learning curve theory to construction projects and the 16.3 per cent of respondents who believed it was not possible was obtained in Question 7 and analysed. The respondents' answers to this question, which required them to rate each identified concept as an identical, repetitive, or continuous factor, were regarded as important.

The top 10 concepts identified according to the methods used in the current study are shown in Table 3.

Table 3: Top 10 concepts for all respondents and for the respondents with personal beliefs (see online for colour version)

\begin{tabular}{|c|c|c|}
\hline All responses & Q6 = yes & Q6 = no \\
\hline Project specifications (1) & Project specifications (1) & Project specifications (1) \\
\hline Design (2) & Scope (3) & Design (2) \\
\hline Scope (3) & Design (2) & Scliverabe (3) \\
\hline Budget (4) & Construction crew experience & Budget (4) \\
\hline Site management (5) & $\begin{array}{c}\text { Planning, monitoring, and } \\
\text { controlling (6) }\end{array}$ & $\begin{array}{c}\text { Planning, monitoring, and } \\
\text { controlling (6) }\end{array}$ \\
\hline $\begin{array}{c}\text { Construction crew experience } \\
\text { Quality (7) } \\
\text { controlling (6) }\end{array}$ & $\begin{array}{c}\text { Site management (5) } \\
\text { Quality (7) }\end{array}$ & $\begin{array}{c}\text { Using the same } \\
\text { suppliers/fabricators }\end{array}$ \\
\hline Project manager & Contractor/client relationship & Sudget (4) management (5) \\
\hline Contractor/client relationship & & Quality (7) \\
\hline
\end{tabular}

The colours and numbers shown in Table 3 indicate the correlation between the results obtained in all the responses and those with different personal beliefs. Only the concepts identified in the top 10 list are coloured and numbered. The numbering refers to the position obtained in the mean rank value from the Friedman test.

As illustrated in Table 3, seven of the concepts appear in the top 10 list of concepts identified by each of the three analyses employed. These concepts are:

- $\quad$ Project specifications

- Design

- Scope

- $\quad$ Budget

- $\quad$ Site management

- $\quad$ Planning, monitoring, and controlling

- Quality

A further three concepts occur in the top 10 list of two of the three analyses employed. These concepts are:

- $\quad$ Project manager

- Construction crew experience

- Contractor/client relationship

It can be noted that the respondents who believed it was not possible to apply the learning curve theory to construction projects ranked 'deliverables' and 'client' as important concepts for the 
successful application of the learning curve theory to construction projects. They also attached little importance to the concept of 'construction crew experience', whereas the other responses analysed with the other methods revealed it to be important. Further investigation into the reason for this finding might prove valuable, and could be a topic for future research. The respondents who believed it was not possible to apply the learning curve theory to construction projects expressed such a strong opinion about the importance of the concept of 'project manager' that this concept made it to the top 10 list for all responses; this, even though the respondents who believed it was possible to apply the learning curve theory to construction projects, and who far outnumbered those who did not believe it was possible, did not rank 'project manager' as one of the top 10 concepts. 'Project manager' features on the top 10 list for all responses based on the ranked mean and weighted mean methods. It is the opinion of the author that 'construction crew experience' and 'project manager' are important, and should, in fact, be considered as critical concepts.

It must be noted that, for the learning curve theory to be successfully applied to construction projects, all 50 identified concepts need to be valid. In practice, the possibility that all 50 concepts will be identical to a previous project is very slim. For the purpose of this research, the seven concepts identified above are seen as the most important concepts and as equally important. Should only the top seven concepts correspond between two projects, the chances of successfully applying the learning curve theory increase; however, the level and degree of correspondence are not clear. Further research will be required to identify the exact impact of each individual concept on the successful implementation of the learning curve theory on construction projects.

The importance of the outcome of this research is far-reaching, in that all construction companies, contractors, sub-contractors, and specifically companies specialising in EPCM construction contracts, are better placed to understand the application of the learning curve theory. Having knowledge of the identified concepts, these companies and individuals can educate their clients, and use this research to substantiate the project durations they estimate in their tenders for construction projects. By implication, more successful projects will be completed on time and within budget. The fact that the learning curve theory is applicable to construction projects only to a certain degree is of great financial importance to companies. The complete set of criteria is now available that can be used either as motivation to implement this theory with a view to negotiating a reduced schedule and/or budget, or as motivation to disregard any possible implementation of the learning curve theory and, therefore, to renegotiate with a view to increasing a project schedule and/or budget.

Although the research participants are situated in South Africa, the data collected to test the theoretical framework is based on the international project experience of these participants, and therefore the data characteristics should be considered in interpreting the application of the findings. The findings of this research are relevant for construction practitioners in other geographic areas that use EPCM contracting methodologies.

\section{REFERENCES}

[1] Yelle, L.E. 1979. The learning curve: Historical review and comprehensive survey, Decision Sciences, 10(2), pp. 302-328.

[2] Stump, P.E. 2004. All about learning curves. [online] Available from http://www.galorath.com/images/uploads/LearningCurves1.pdf. Accessed: 15 September 2015.

[3] Henderson, B.D. 1984. The application and misapplication of the experience curve, Journal of Business Strategy, 4(3), pp. 3-9.

[4] Hodder, J.E. and Ilan, Y.A. 1986. Declining prices and optimality when costs follow an experience curve, Managerial and Decision Economics, 7(4), pp. 229-234.

[5] Cunningham, J. 1980. Management: Using the learning curve as a management tool: The learning curve can help in preparing cost reduction programs, pricing forecasts, and product development goals, IEEE Spectrum, 17(6), pp. 45-48.

[6] Thomas, H.R., Mathews, C.T. and Ward, J.G. 1986. Learning curve models of construction productivity, Journal of Construction Engineering and Management, 112(2), pp. 245-258.

[7] Caruso, J. 2002. Project management success and the learning curve. [online] Available from http://blog.joecaruso.ca/wp-content/uploads/2009/08/Project-Management-Success-and-the-LearningCurve.pdf. Accessed: 15 September 2015.

[8] Pellegrino, R., Costantino, N., Pietroforte, R. and Sancilio, S. 2012. Construction of multi-storey concrete structures in Italy: Patterns of productivity and learning curves, Construction Management and Economics, 30(2), pp. 103-115. 
[9] Parker, H.W. and Oglesby, C.H. 1972. Methods improvement for construction managers. New York: McGraw-Hill.

[10] Gottlieb, S.C. and Haugbølle, K. 2010. The repetition effect in building and construction works: $A$ literature review. Hørsholm: SBI Forlag.

[11] Project Management Institute. 2013. A guide to the project management body of knowledge (PMBOK Guide). 5th ed. Newtown Square, PA: Project Management Institute.

[12] Project Management Institute. 2007. Construction extension to PMBOK Guide. 3rd ed. Newtown Square, PA: Project Management Institute.

[13] Schwartzkopf, W. 2004. Calculating lost labor productivity in construction claims. New York: John Wiley and Sons.

[14] Hattingh, E., van Waveren, C.C. \& Chan, K.-Y. 2018. The Criteria for Implementing the Learning Curve Theory on Construction Projects. in International Association for Management of Technology (IAMOT). pp. 1-20.

[15] Hsu, C. and Sandford, B.A. 2007. The Delphi technique: Making sense of consensus, Practical Assessment, Research \& Evaluation, 12(10), pp. 2-5.

[16] Watkins, J.A. 2012. Theses/Dissertations/Research Reports: A practical guide for students to the preparation of written presentations of academic research. Vol 2. Cape Town: Lavender Moon.

[17] Likert, R.A. 1932. A technique for the measurement of attitudes, Archives of Psychology, 140, pp. 1-55.

[18] Fink, A. 1995. How to design surveys. London: Sage.

[19] Nulty, D.D. 2008. The adequacy of response rates to online and paper surveys: What can be done? Assessment \& Evaluation in Higher Education, 33(3), pp. 301-304. 